\title{
Judicial Recognition of Constitutional Conventions: The Elements Revisited
}

\author{
Moha. Waheduzzaman*
}

\section{Introduction}

In the study of constitutional law, it is now firmly established that two sets of rules should be remembered to fully apprehend the constitution of a country. ${ }^{1}$ Those rules are commonly referred to as the 'laws of the constitution' and 'conventions of the constitution'. In countries, where there are written constitutions, the laws of the constitution are usually contained in that written document and their violation also entails legal consequences. On the other hand, the conventions of the constitution usually grow up around and upon the principles of the written constitution of a country. ${ }^{2}$ Regarding the growth of conventions in the constitutional system of a country, Hood Phillips observes: "With passage of time, in working a constitution and running the state affairs, many precedents occur and practices develop. When such precedents and practices are found to have been consistently followed, they are

PhD candidate at the University of Dhaka and Assistant Professor, Department of Law, University of Dhaka, Bangladesh.

1 Dicey, who was much anxious in English jurisdiction to distinguish conventions from laws on the basis of their 'court enforceability', also recognizes the need of having knowledge of conventions to fully apprehend a constitution. To express in Dicey's own words: "But a lawyer cannot master even the legal side of the English constitution without paying some attention to the nature of those constitutional understandings which necessarily engross the attention of historians or of statesmen. He ought to ascertain, at any rate, how, if at all, the law of the constitution is connected with the conventions of the constitution; and a lawyer who undertakes this task...to the English polity the whole of its peculiar colour." Albert V. Dicey, Introduction to the Study of the Law of the Constitution (10 ${ }^{\text {th }}$ edn, MacMillan Press 1959) 417-18.

2 Ivor Jennings, The Law and the Constitution ( $5^{\text {th }}$ edn, University of London Press 1972) 83. Jennings mentions in this regard the conventions of the US Constitution: "Thus a whole host of conventions has grown up around and upon the Constitution of the United States, regulating, for instance (apart from legislation, which also applies), the method of electing the President, the composition and operation of his Cabinet, his relations with Congress, and so on." ibid (internal citation omitted). Mahmudul Islam also cites from US Constitution: "Many conventions have also developed in the United States relating to election of the President, the formation, selection and functioning of the President's Cabinet, senatorial approval of certain political appointments and other matters." Mahmudul Islam, Constitutional Law of Bangladesh ( $3^{\text {rd }}$ edn, Mullick Brothers 2012) 4. In passing, it may, therefore, be noted that conventions are peculiar not only to unwritten constitutions, as in Great Britain, but may be found to a greater or lesser extent in countries with written constitutions as well. Wheare realizes to this effect that "in all countries usage and convention are important and that in many countries which have Constitutions usage and convention play as important a part as they do in England." KC Wheare, Modern Constitutions ( $2^{\text {nd }}$ edn, Oxford University Press 1966) 122. AV Dicey was also well aware of this when he observed in relation to US Constitution that "It may be asserted without much exaggeration that the conventional element in the Constitution of the United States is as large as in the English Constitution." Cited in Wheare, ibid. 
treated as constitutional conventions." practice" and regarded commonly as the "non-legal" rules of a constitution. These conventions or 'unwritten rules' ${ }^{6}$ are found in almost all established constitutions and also soon developed even in the newest ones.

The conventions, therefore, are also not uncommon to the written constitutional law of Bangladesh. However, the moot question that has vexed the Supreme Court of Bangladesh in dealing with them is whether they are enforceable in a court of law or not. One may find conventions of many and varied dimensions in actual working of the constitutional governmental system of Bangladesh. But the only constitutional practice of political actors that has come before the court and judges have also discussed the issue at some length is the convention of President's 'consultation' with the Chief Justice in the matter of appointment of Judges of the Supreme Court of Bangladesh. Article 95(1) of the original Constitution of 1972 provided that "the Chief Justice shall be appointed by the President and other Judges shall be appointed by the President after consultation with the Chief Justice." 7 Likewise, the President was also required to consult the Chief Justice to appoint Additional Judges under Article 98 of the Constitution. By the Constitution (Fourth Amendment) Act, $1975^{8}$, the phrase 'after consultation with the Chief Justice' was omitted both from Articles 95 and 98 of the Constitution. ${ }^{9}$

However, despite the deletion of the expression 'consultation' by the Fourth Amendment, all appointments as Judges of the Supreme Court were in fact made by the President after consultation with the Chief Justice and that was so made even "during the Martial Law regime though the matter of consultation was not reflected in the Notification." 10 This conventional consultation was breached only once by the Executive in 1994 when 9 Additional Judges were appointed to the High Court Division without consultation with the Chief Justice. Following a protest, however, the Notification "was rescinded and fresh appointments were made, recognizing in the fresh Notification itself, that the appointments were made in consultation with the Chief Justice." $" 11$

\footnotetext{
O Hood Phillips, Constitutional and Administrative Law $\left(7^{\text {th }}\right.$ edn, Sweet \& Maxwell) 77. ibid 28.

For example, O Hood Phillips regards conventions not laws as they are "not enforced by the Courts or by the House of Parliament." ibid.

6 The accuracy of using the expression 'unwritten rules' to describe conventions has been discussed in brief in the next Part of the study under the heading "The Meaning of Constitutional Conventions". See, generally notes 35 to 43 and the accompanying texts.

Emphasis added.

The Constitution (Fourth Amendment) Act 1975 (Bangladesh).

9 The said phrase was restored to Article 95 by the Second Proclamation (Seventh Amendment) Order, 1976 [Second Proclamation Order No. VI of 1976] but was soon omitted by the Second Proclamation (Tenth Amendment) Order, 1977 [Proclamation Order No. I of 1977] and finally by the Constitution (Fifth Amendment) Act, 1979 [Act I of 1979].

11 Mustafa Kamal, Bangladesh Constitution: Trends and Issues ( $2^{\text {nd }}$ edn, University of Dhaka 1994) 30.
} 
This convention of 'consultation' in the matter of appointment of Judges has been the subject matter of dispute and discussion in some leading cases before the Supreme Court of Bangladesh. The cases are: State v Chief Editor, Manabjamin ${ }^{12}$; Idrisur Rahman v Bangladesh ${ }^{13}$; and, Bangladesh v Idrisur Rahman ${ }^{14}$. The Appellate Division of the Supreme Court, in the specific context of Idrisur Rahman $(A D)^{15}$ where the question concretely arose for determination, held in favour of 'court enforceability' of the convention of 'consultation'. In view of the binding nature of the decision of the Higher Judiciary as declared by Article 111 of the Constitution, the Idrisur Rahman $(A D)^{16}$ decision of the Appellate Division of the Supreme Court may be said to represent the law regarding the status of constitutional conventions in Bangladesh. It may also be pertinent to mention in this regard that the Supreme Court of Bangladesh in all three cases ${ }^{17}$ dealing with conventions relied heavily as to whether or not the constitutional practice of 'consultation' by the political actors has become an established conventional rule in course of time to reach their conclusions.

The question regarding the enforcement of constitutional conventions in a court of law also came up for judicial consideration before the Supreme Court of India. Dealing with the question, Kuldip Singh J of the Indian Supreme Court held his views as under:

We are of the view that there is no distinction between the "constitutional law" and an established "constitutional convention" and both are binding in the field of their operation. Once it is established to the satisfaction of the court that a particular convention exists and is operating then the convention becomes a part of the "constitutional law" of the land and can be enforced in the like manner. ${ }^{18}$

The above mentioned view of the Indian Judge may be stated to represent in general the status of constitutional conventions within the framework of its constitution. The judges of the Supreme Court of Bangladesh built mainly on this view of the Indian Judge. In all three cases dealing with conventions, the judges cited with approval the above quoted view of Kuldip Singh $\mathbf{J}^{19}$ so as to form their opinion to enforce judicially an established constitutional convention and, accordingly, enforced in Idrisur Rahman $(\mathrm{AD})^{20}$ the convention of 'consultation' regarding the appointment of Judges of the Supreme Court against the executive government of the state. It is at

(2005) 57 DLR (HCD) 359 (hereinafter Manabjamin).

(2009) 61 DLR (HCD) 523 (hereinafter Idrisur Rahman (HCD)).

(2010) 15 BLC (AD) 49 (hereinafter Idrisur Rahman (AD)).

ibid.

ibid.

Manabjamin (n12), Idrisur Rahman (HCD) (n13) and Idrisur Rahman (AD) (n 14).

S.C. Advocates-on-Record Association v India (1994) AIR (SC) 268,404.

Manabjamin (n 12) 453 and 455, Idrisur Rahman (HCD) (n 13) 542 and 579, and Idrisur Rahman (AD) (n 14) 90.

Idrisur Rahman (AD) (n 14). 
this point that the present author felt an urge to write on the nature and status of constitutional conventions for the author could not at all agree with the views or stand taken by the Supreme Court of Bangladesh on some significant aspects of conventions.

In view of the author, in course of its judgment in Idrisur Rahman (AD) ${ }^{21}$ the Appellate Division of the Supreme Court of Bangladesh adopted erroneous view of laws and conventions of the constitution on a number of grounds.

First and foremost, the Supreme Court failed to maintain distinction between recognition and enforcement of conventions in a court of law. A court may recognize the existence of a convention but may at the same time deny enforcing the same in the instant case. The distinction is maintained even by courts in England. The Supreme Court relied mostly on English literature, particularly of Jennings, to enforce in its jurisdiction the convention of 'consultation'. ${ }^{22}$ True, Jennings provided some standard tests to determine the existence of a convention, but not that he did not maintain distinction between recognition and enforcement of conventions. The Idrisur Rahman (AD) ${ }^{23}$ decision of Bangladesh Supreme Court makes no discussion on this aspect (recognition and enforcement) of the distinction between laws and conventions of the constitution. The Supreme Court simply applied the Jennings test to determine in its jurisdiction the existence of the convention of consultation, found it as an established convention and enforced it in the instant case. This particular pattern of analysis and judgment leaves the author with no option but to hold that the Court in fact could not appreciate the distinction between recognition and enforcement of conventions in a court of law. One may, in this context, argue that the Supreme Court understood the distinction but did not find it necessary to analyze the point. This contention cannot be accepted because, in such a case, it may be counter argued, the Supreme Court was of necessity bound to distinguish the situations of Bangladesh from that of English jurisdiction so as to justify its not maintaining the distinction since for basis of its judgment it relied heavily on English literature where the distinction is maintained. But the Supreme Court did not also distinguish the situations of Bangladesh from that of English jurisdiction. Thus, the Supreme Court neither did feel it necessary to draw distinction between recognition and enforcement of conventions in a court of law nor to distinguish between the two jurisdictions so as to justify its not maintaining such distinction.

Second, the Supreme Court also failed to appreciate distinction between the expressions unconstitutional and unlawful as maintained in English jurisdiction. This

21 ibid.

22 For the Appellate Division's heavy reliance on English authority in Idrisur Rahman (AD), see, Idrisur Rahman (AD) (n 14) 88-92.

23 Idrisur Rahman (AD) (n 14). 
failure expedited the Court's enforcement of the convention of 'consultation' immediately after it could establish its existence without entering into any further inquiry as to the attending circumstances and conditions that may be regarded necessary for judicial enforcement of conventions in a given case.

Third, the Supreme Court did not find any distinction between laws of the constitution and an established constitutional convention. Thus, on this view of the Court, the status of 'laws of constitution' and an 'established convention' are same in its jurisdiction. It is submitted that the Court has been influenced by the writings of Jennings to hold an extreme view such as this. Dicey held the distinction between laws and conventions of the constitution on the ground of their 'court enforceability'. True, Jennings provided a different explanation from that of Dicey but only to exemplify the fact that the distinction is not as simple and unambiguous as Dicey suggested or contemplated. Jennings, the author begs to argue, even after his different explanation, maintained the distinction between conventions and laws of the constitution strictly so called and — importantly and interestingly — he, too, maintained the distinction mainly on the ground of their enforceability in a court of law.

In the backdrop of the above mentioned failures of Bangladesh Supreme Court, the author undertakes this study to reflect on the nature and status of conventional rules within the framework of Bangladesh Constitution. The author, however, submits that any research study to accomplish this broad task should revolve mainly around these five questions. First, how should a court determine or establish the existence of conventions in its system? This deals with the recognition criteria of conventions in any constitutional system. Second, should there be any distinction between laws and established conventions of constitution? Third, how should a court differentiate between mere judicial recognition and actual judicial enforcement of conventions in a concrete case? These questions for an adequate answer require a thorough and critical comparative discussion between laws and established conventions of the constitution. Fourth, what significance may still remain of conventions if laws and conventions of the constitution are accepted to be different from each other in terms, inter alia, of their recognition and enforcement in a court of law? The answer to the question reflects on the nature of operation of conventions i.e. the effect in practice of the operation of conventions on laws of constitution, or how the two sets of rules interact with each other in actual functioning of the governmental system of a country. Fifth, how should a court determine the conditions and circumstances of judicial enforcement of an established constitutional convention? This specifically deals with the issues or concerns of actual judicial enforcement (as opposed to mere judicial recognition) of established conventions within the framework of any given constitution. 
It is obvious that in a single research article one cannot seek to answer all of the above enumerated questions pertaining to any broad overall research venture reflecting on the nature and status of constitutional conventions. The present author has not been any exception to this as well. To the best of the knowledge of the author, there has not been any published research work in Bangladesh addressing any one of the above mentioned aspects of the conventional rules of constitution. Since no research work has yet been undertaken on the subject, the present author prefers in this study to pursue the first of the above enumerated questions i.e. the question of judicial recognition of conventions in a constitutional system.

Besides the laws of the constitution, one should also have enough mastery on conventions of the constitution to fully comprehend its constitutional system. Superior Courts on occasions, as has happened for Bangladesh Supreme Court in Idrisur Rahman ${ }^{24}$, recognize and enforce constitutional conventions in appropriate cases. Again, apart from the courts, any person responsible for constitutional interpretation or interested in constitutional law needs also to learn the interaction between laws and conventions of its constitutional system. In all these cases, either the judge or any such person should know, first of all, whether the particular convention with which he is dealing does in fact exist or not in its constitutional system. Before deciding on the interactive effect or enforceability status of conventions, confusion may arise as to the very existence of the convention itself. Hence, judges, lawyers and academicians dealing with any convention would require establishing in its system the existence of the conventional rule first.

But no research study (even globally) has yet been undertaken focusing exclusively on the constituent elements of a convention. In such a vacuum, the present study seeks to reflect on the essential elements of a convention that may be regarded necessary to be fulfilled before a court may give recognition to (and if necessary to enforce thereof) a convention in a given case. The study, the author believes, would attain two-fold objectives in the field of constitutional law. First, it would help one identifying the existence of any convention in its system and also help to understand better the nature of conventional rules of its constitutional system. Second, the first attained objective, in turn, would help facilitating the judges, lawyers and any academic researcher in the respective field to inquire into further questions or issues on conventions, such as, how to draw distinction between laws and established conventions of constitution, what in practice is the interactive effect of conventions on laws of constitution, and finally how to determine on the enforceability status of a particular convention in its system. Thus, the present study though limited only to reflecting on the recognition criteria of conventions, may, from a broader perspective, contribute to the overall better understanding and 
appreciation of the laws and conventions of any state constitutional jurisdiction in general.

At the outset, however, one thing should be made clear. The author, in the present study, does not claim to create the constituent elements of conventions de novo. The standard tests provided by Jennings in this regard are followed consistently both in the scholarly literature and by the courts of divergent jurisdictions. The Supreme Court of Bangladesh and Canada, for example, have adopted the Jennings test to determine within their respective jurisdictions the existence of particular conventions. ${ }^{25}$ But thus far no research undertaking has been taken to examine in detail or elaborate on the views of Jennings that comprise the constituent elements of a convention. This is what is omitting in the existing constitutional law literature which the author attempts to supply in the present research study.

To accomplish the task of the study, the author has divided it into four Parts. Part 1 introduces one with the background, rationale and significance of the study. Part 2 attempts to form a general and preliminary understanding of the meaning of constitutional conventions with a view to entering into a far more rigorous analysis of the essential elements of conventions in the immediately following Part of the study. Part 3 takes note of and examines in detail all those essential elements that constitute a convention. In course of its analysis, it identifies the lead characteristic mark of conventions and on that basis also seeks to distinguish them from the three other 'non-legal' concepts of constitution: habits, understandings and practices. In any system, one understands better what a thing is when he understands what the thing does for the system. The study, therefore, in this Part also undertakes an inquiry into the purposes these conventions serve for the constitutional system of a country. This, however, has been done not in isolation of or by means of a full-fledged separate study on purposes but as component of one of the essential elements of convention. Part 4 concludes by summarizing the findings and arguments of the study.

\section{The Meaning of Constitutional Conventions}

What are conventions of the constitution? There is a fairly lengthy literature on the subject but the author found the classic exposition of Ivor Jennings most appropriate and convenient as the starting point for the discussion. Regarding the inevitable nature of conventions in the system of government, Jennings wrote:

25 Bangladesh Supreme Court in Idrisur Rahman (AD) (see, (n14)) applied the Jennings test to establish within its jurisdiction the convention of 'consultation' in the matter of appointment of Judges of the Supreme Court. The Canadian Supreme Court applied the same test in Patriation Reference (see, (n 72)) to determine within its jurisdiction the existence of a convention that the 'Constitution of Canada cannot be amended without first obtaining the consent of the Provinces.' 
But men being what they are, they tend to follow rules of their own devising; they develop habits in government as elsewhere...Indeed, people begin to think that the practices ought to be followed. It was always so done in the past, they say; why should it not be done so now? Thus within the framework of the law there is room for the development of rules of practice, rules which may be followed as consistently as the rules of law, and which determine the procedure which the men concerned with government must follow. ${ }^{26}$

Thus, the constitutional authorities "who take decisions create precedents which others tend to follow, and when they have been followed long enough they acquire the sanctity and the respectability of age." ${ }^{27}$ Such precedents of political and constitutional actors may or may not be followed in subsequent cases but a series of precedents all pointing in the same direction surely evidences for a particular body of rules existing in the constitutional system. After being so established, these rules carry the idea that "they not only are followed but they have to be followed" 28 in future similar cases. This precisely is the idea of this body of 'non-legal' rules of the constitution. They have been given various names by authors of different ages of some recognized merit. To quote Ivor Jennings again:

These rules Mill referred to as "the unwritten maxims of the constitution." Twenty years later Dicey called them "the conventions of the constitution" while Anson referred to them as "the custom of the constitution." 29

Jennings found all of the above expressions to be problematic since, in his view, none of the phrases exactly expresses what is actually meant by this body of rules of the constitution. ${ }^{30}$ The expression 'unwritten maxims' of Mill is problematic since the judge made common law of England are also as 'unwritten' "as those outside the

26 Jennings (n 2) 80. As to the inevitable nature of conventions in the system of government, this view of Holdsworth is also illuminating: "Conventions must grow up at all times and in all places where the powers of government are vested in different persons or bodies - where in other words there is a mixed constitution. 'The constituent parts of a state, said Burke, are obliged to hold their public faith with each other, and with all those who derive any serious interest under their engagements, as much as the whole state is bound to keep faith with separate communities.' Necessarily conventional rules spring up to regulate the working of the various parts of the constitution, their relation to one another and to the subject." William Holdsworth, 'The Conventions of the Eighteenth Century Constitution' 71 Iowa Law Review 162. Quoted in Jennings (n 2) 82 (internal citation omitted). ibid.

Jennings (n 2) 81(internal citations omitted). Regarding the existence of this body of rules, this brief description of Jennings is also illuminating: "There is a whole complex of rules outside 'the law', nowhere inconsistent with it but nowhere recognized by it, which can be stated with almost as much precision as the rules of law. Such rules have been set out by many authorities; they are discussed in Parliament; they are appealed to whenever dispute arises. They are called by various names, but are now commonly referred to as 'constitutional conventions'." Jennings (n 27) 2 (internal citations omitted). 
law." ${ }^{\prime 31}$ Similarly, the term 'convention' coined by Dicey is also problematic since it always "implies some form of agreement, whether expressed or implied" 32 , while the expression 'custom' employed by Anson "assumes first that the law enforced in the courts need not be custom, and secondly that an extra-legal rule cannot be created by express agreement." 33 Despite these difficulties, Jennings preferred to employ the term 'convention' in his book The Law and the Constitution and the present author has also used the same expression for this body of rules of the constitution in this study since the phrase of Dicey has acquired general acceptance or "has now been sanctioned" 34 by many years of common use by judges of divergent jurisdictions as well as the authors of constitutional law.

However, by whatever name one may prefer to call them, KC Wheare has indicated that there are at least two sources for this body of 'non-legal' rules of the constitution to come into existence. ${ }^{35}$ Sometimes a course of conduct may persist in for "over a long period of time and gradually attain first persuasive and then obligatory force. ${ }^{36}$ Wheare views them as conventions arising out of 'custom' ${ }^{37} \mathrm{He}$, however, further reiterates that "a convention may arise much more quickly than this." 38 This may happen where there is an "agreement among the people concerned to work in a particular way and to adopt a particular rule of conduct." 39 This rule is "immediately binding" and it is, Wheare says, a convention. ${ }^{40}$ For conventions of this latter kind Wheare observes as follows:

It has not arisen from custom; it has had no previous history as a usage. It springs from agreement. Its basis is indeed very like that of the conventions which are drawn up in international relations. They are held to be morally binding and politically binding, but until they are enacted by the appropriate machinery of a state they do not in most countries alter the law or form part of the law. ${ }^{41}$

Conventions, therefore, are not necessarily and not always the 'unwritten' rules of a constitution. Keeping in view the conventions of this latter kind which arise from agreement and might easily be written down, Wheare stresses how unsatisfactory is the distinction between law and convention as being the 'written' and 'unwritten'

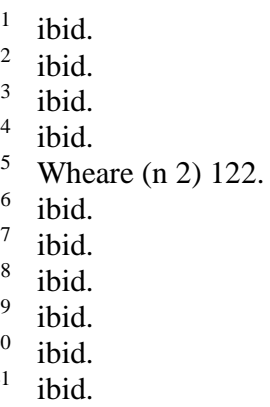


rules of the constitution. ${ }^{42}$ It is a distinction, Wheare emphasizes, "which is seldom applied accurately and is seldom, if ever, profitable." ${ }^{43}$ While this view of Wheare may hold good or true in the context of English constitutional law (and may indeed be applicable for some other jurisdictions as well), there is no reason it should be taken to be of universal application. In Bangladesh, for example, being based mainly on custom and precedent (precedent not in the sense of 'case law' but as 'practices' of political and constitutional actors), constitutional conventions are usually the 'unwritten' rules of the constitution.

Before parting with this Part of the study, it would be pertinent to take note of an interesting fact that "matters which in one country are regulated substantially by usage and convention are in others regulated by law." $" 44$ Conventions are not only "reduced to writing but also enacted as part of the Constitution." 45 To mention just a few, In England, the Queen has the legal right to refuse to give the royal assent to Bills passed by the House of Commons and Lords. By convention, the Queen must assent to such Bills unless advised to the contrary by her government. This conventional rule of the UK Constitution has been enshrined in Article 80 of Bangladesh Constitution. Again, the Queen in England will appoint, by convention, as Prime Minister the leader of the political party with the majority of seats in the House of Commons. Article 56(3) of Bangladesh Constitution embodies this conventional provision of the UK Constitution. To cite yet another example, in England, the ministers of the Crown are by convention both individually and collectively responsible to the parliament. In Bangladesh, the provision for collective ministerial responsibility has been ensured in Article 55(3) of the Constitution.

The above cited examples are by no means intended to be exhaustive for the purpose, but are only to give a flavour of the nature and forms of constitutional conventions of one country that may form part of the written constitutional law of another country. To conclude this Part of the study, one should finally remember that constitutional law together with constitutional convention make up the total constitution of a country. After having these general understandings of constitutional conventions, the author may now turn into the more rigorous analysis of the elements

42 ibid 123. Dicey also did not mean by conventions the 'unwritten rules' of English Constitution. He sought to clarify: "The one exception which can be taken to this picture of our conventional constitution is the contrast drawn in it between the "written law" and the "unwritten constitution"; the true opposition as already pointed out, is between laws properly so called, whether written or unwritten, and understandings, or practices, which, though commonly observed, are not laws in any true sense of that word at all. But this inaccuracy is hardly more than verbal, and we may gladly.... which make up our body of constitutional morality." Dicey (n 1) 420. Wheare ibid. ibid 133. ibid. 
of constitutional conventions that need to be fulfilled before a court may give recognition to (and if necessary to enforce thereof) a convention in a given case.

\section{The Elements of a Constitutional Convention}

One may ask this straightforward question: when is it possible to say that a convention has been established? Jennings very categorically answers: "We have to ask ourselves three questions: first, what are the precedents; secondly, did the actors in the precedents believe that they were bound by a rule; and thirdly, is there a reason for the rule?" ${ }^{46}$ Nobody has yet come forward with a better explanation than this regarding the standards to determine the existence of a convention in any constitutional system. Three essential characteristic features of a constitutional convention emerge from the test adopted by Jennings: precedent, normativity (rule) and reason for the rule. The elements need some elaboration and the author begins to deal first with precedent.

\subsection{Precedent}

It is worth mentioning at the outset that conventions are not precedents of a 'court of law' and as such not prima facie authoritative like judicial precedents. And more obvious than this is the fact that they are also not in the nature of statutory commands which it is the function and duty of the courts to obey and enforce. They are simply acts (or omissions) of political and constitutional actors or institutions of government of a state. If in a situation there is no act of the authorities, there is no firm convention regulating the situation. Therefore, to satisfy the existence of a convention, first of all, one must establish that the constitutional actors behaved in the past in a certain way governing a particular question of constitutional importance. Every act of the constitutional authorities in this sense is a precedent. But not every precedent creates a rule and as such also not a convention. This turns on the normative aspect of the rule, the second characteristic feature of a convention.

\subsection{Normativity}

It would be profitable, in view of the author, to begin discussion of this Section of the study with reference to the oft-quoted passage from AV Dicey's Introduction to the Study of the Law of the Constitution. In this Book, Dicey expressed his views on the two sets of rules that make up the English Constitution as under:

The rules which make up constitutional law, as the term is used in England, include two sets of principles or maxims of a totally distinct character.

The one set of rules are in the strictest sense 'laws', since they are rules which (whether written or unwritten, whether enacted by statute or derived from the mass

46 Jennings (n 2) 136. 
of custom, tradition, or judge made maxims known as the common law) are enforced by the Courts; these rules constitute 'constitutional law' in the proper sense of that term, and may for the sake of distinction be called collectively the law of the constitution.'

The other set of rules consist of conventions, understandings, habits or practices which, though they may regulate the conduct of the several members of the sovereign power, of the Ministry of the other officials, are not in reality laws at all since they are not enforced by the Courts. This portion of constitutional law may, for the sake of distinction, be termed the 'conventions of the constitution', or constitutional morality. ${ }^{47}$

This view of Dicey involves two important aspects in relation to the study of the nature and status of conventional rules of the constitution. First, Dicey equates or rather to employ the more accurate and exact terms has not drawn any distinction between 'conventions' at the one hand and the other apparently seeming concepts used by Dicey himself, such as, 'habits, understandings and practices' at the other hand. Second, Dicey draws distinction between 'laws' and 'conventions', but that is so drawn only on the basis of their 'court enforceability' ignoring or without mentioning at all the other aspects of their similarities and/or dissimilarities. While one may certainly find these limitations of Dicey's work, the present author, however, besides this, would seek to elucidate the nature and status of conventional rules on the basis of, inter alia, the two aspects identified from Dicey's analysis itself. However, in the present study, the author shall deal only with the lead characteristic mark of conventions and how on that basis they may be different from the other "nonlegal' concepts of the constitution. ${ }^{48}$

\subsubsection{The Main Characteristic of a Convention}

Dicey's analysis ${ }^{49}$ suggests that 'conventions' are of the same quality as 'understandings, habits or practices'. They are, however, not really so. But how may one distinguish conventions from these other apparently seeming concepts of a constitution? To distinguish conventions from these concepts of a constitution, it is necessary first to identify the main characteristic mark of convention itself. It is indeed the idea of a 'rule' which is central to the understanding of conventions and on that basis they may be distinguished from these other 'non-legal' concepts of a constitution.

47 Albert V. Dicey, Introduction to the Study of the Law of the Constitution (MacMillan Press 1885) 23, 24 (emphasis added). This view has been reiterated in a latter edition also: "it is seen to consist of two different parts; the one part is made up of understandings, customs, or conventions which, not being enforced by the courts, are in no true sense of the word laws; the other part is made up of rules which are enforced by the courts, and which, whether embodied in statues or not, are laws in the strictest sense of the term, and make up the true law of the constitution." Dicey (n 1) 469-70. 
A 'rule' is usually defined as "a statement prescribing the conduct which is required in a given situation and which imposes an obligation on those who are regulated by the rule". ${ }^{50}$ HLA Hart, in his The Concept of Law, took recourse to some strands of distinction to make clear the idea of a 'rule'. Those strands of distinction have been summarized by McLeod as the distinction between personal habits and social rules; the distinction between being obliged and being under an obligation; and, the distinction between external and internal aspects of rules. ${ }^{51} \mathrm{~A}$ thorough analysis of Hart's understandings of law as 'system of rules' is not the object of this article as well as his in depth analysis of the several strands of distinction in relation to a 'rule' also falls beyond the limited scope of the present study. It would suffice here only to produce his arguments on the internal aspects of rules which are very much reflective of the characteristic features of a 'rule'. In Hart's own words:

What is necessary is that there should be a critical reflective attitude to certain patterns of behaviour as a common standard, and that this should display itself in criticism (including self-criticism), demands for conformity, and in acknowledgments that such criticism and demands are justified, all of which find their characteristic expression in the normative terminology of "ought", "must", and "should", "right" and "wrong". ${ }^{2}$

One may identify a number of features of a 'rule' from this analysis of Hart. However, the present author prefers to take into account three characteristic features of a 'rule' that seem to appear very prominently from this analysis of Hart and also relevant for purposes of the present study. First, rules involve the idea of obligations or, in other words, rules create obligations. For a person to be under an obligation, there must exist a rule. To state in negative terms, when there is no rule there is no obligation. To give one common example, suppose, a gunman, A, demands money from a victim, B. According to the ordinary use of language, one "would say that B is obliged to hand over the money (because he fears the consequences if he does not do so), but one would not say that B is under an obligation (or owes a duty) to comply with A's demand.. ${ }^{, 53}$ The command of the gunman was no more than an order backed by threats and not a 'rule' and as such creating no 'obligations' for the victim B to comply with. Second, the obligation - created by a 'rule' - is 'normative' in character. By this is meant that the rule is 'prescriptive' - prescriptive of what 'ought' or 'ought not' to be done as a course of conduct in a given case. It thus dictates the appropriate form of action in a particular situation. Third, breach or violation of the 'rule' (that is to say, the 'obligation') gives rise to a legitimate ground for criticism.

50 Hilaire Barnett, Constitutional and Administrative Law ( $4^{\text {th }}$ edn, Cavendish Publishing 2002) 28.

$51 \quad$ Ian McLeod, Legal Theory ( $2^{\text {nd }}$ edn, Palgrave Macmillan 2003) 77.

52 HLA Hart, The Concept of Law ( $2^{\text {nd }}$ edn, Clarendon Press 1994) 57.

53 McLeod (n 51) 78 (emphasis in original). 


\subsubsection{Distinguishing Conventions from other Non-Legal Concepts of Constitution}

Conventions of the constitution involve the idea of a 'rule' with characteristic features identified and analyzed above. And on this basis, one may seek to distinguish 'conventions' from 'habits, understandings and practices', the other 'non-legal' concepts of the constitution.

\section{a. Habits}

It has now been very common to cite the example of tea or coffee drinking to distinguish habits from any normative idea. The present author also uses here the same example. Suppose, a person invariably drinks tea in the afternoon. Is the fact of drinking tea a 'habit' or a 'rule' with respect to that person? The fact of drinking tea, when correctly analyzed, is nothing more than an instance of individual behaviour and cannot be called a rule. And it remains so, even if the fact of drinking tea in the afternoon is very widespread in the concerned society. In such a case, it may be a good example of "convergent behaviour" 54 and as such "a large number of instances of individual behaviour" ${ }^{\prime 5}$ but nevertheless not a rule. Because in all such cases the behaviour remains only a descriptive phenomena. It is simply reflective of an actual observable conduct. The observation is a statement of what 'is' and not what 'ought to' be. This is typically the characteristic feature of habits which do not prescribe or dictate what ought to happen but are merely descriptive of what in fact does happen. Furthermore, if the person fails to drink tea in the afternoon, or drinks coffee instead, that action is not going to give rise to any ground for criticism because a mere habit (not being a 'rule') imposes no obligation. It is, however, very different with the breach of a constitutional convention which will invariably give rise to a legitimate ground for criticism. Conventions are thus in this way distinguished from habits.

\section{b. Understandings}

As has already been seen, Dicey also equated the term 'understandings' with conventions of a constitution. The word 'understanding' "connotes a mutual agreement between relevant actors as to the pertinent subject matter, or the manner in which it is appropriate to respond or react to a given situation." ${ }^{, 56}$ Understandings may be brought about by some form of previous conduct or mutual recognition although that may not necessarily be a prerequisite for their existence. ${ }^{57}$ Sometimes, an 'understanding' may well be relied on by the parties, as are conventions. ${ }^{58}$ It is, therefore, necessary for one to learn their distinctions. I quote with approval the following view of Barnett reflecting on the distinction:

\footnotetext{
ibid 77.

ibid.

Barnett (n 50) 29.

ibid.

ibid.
} 
Most importantly, an understanding, while imposing some weak form of moral obligation will not, in the case of failure to comply with its terms, give rise to a sanction in the form of criticism of the same magnitude as that of a breach of a constitutional convention. The explanation for this lies in the fact that an understanding - as opposed to a convention - does not amount to a rule, and accordingly is not obligation imposing to the same degree as a convention. ${ }^{59}$

\section{c. Practices}

Finally, comes the concept of 'practice' for consideration. In our everyday life, it is a commonplace assertion that it is our practice to do the thing in one or the other particular way. This type of statement "conveys the message that past experience of doing something in a particular way is the correct way of proceeding and that, unless there are justifiable reasons for not so doing, the practice will be adhered to." ${ }^{60} \mathrm{~A}$ practice thus differs from a mere habit "on the basis that it imports a notion of reflectiveness, the idea of the 'right' way of reacting to a situation." of reflectiveness in this sense is shared also by conventions of a constitution. How then is a convention different from a practice or usage of a constitution? Barnett draws the subtle differences which I approvingly quote as under:

The borderline between the two is admittedly fine. It may be, however, that the correct dividing line is drawn on the basis of the concept of obligation and rule, and that it is legitimate to argue that whilst a practice imposes some form of weak obligation - and requires some justification for departure from the practice - the practice is no more than an emergent or potential convention and has not yet acquired the binding characteristic of a rule. ${ }^{62}$

Much has been said regarding the lead characteristic mark of conventions, the normativity of precedent. And it is also seen that conventions on this basis may well be distinguished from the three other 'non-legal' concepts of constitution: habits, understandings and practices. However, to give the analysis far more completeness, I may just add in supplement the following eloquent expression of Jennings made in the context of requirement of normativity of a precedent:

It is clear, in the first place, that mere practice is insufficient. The fact that an authority has always behaved in a certain way is no warrant for saying that it ought to behave in that way. But if the authority itself and those connected with it believe

\footnotetext{
ibid (emphasis added).

ibid.

1 ibid (emphasis added).

62 ibid. Wheare also observes the same though couched in a different language: "By 'convention' is meant a binding rule, a rule of behaviour accepted as obligatory by those concerned in the working of the constitution; by usage is meant no more than a usual practice. Clearly a usage might become a convention. What is usually done comes to be what is done. It is often difficult to say whether a particular course of conduct is obligatory or persuasive only, and it is convenient in such a case to be able to say that it is certainly a usage and probably or doubtfully , as the case may be, a convention." Wheare (n 2) 122.
} 
that they ought to do so, then the convention does exist. This is the ordinary rule applied to customary law. Practice alone is not enough. It must be normative. ${ }^{63}$

Jennings justifies the above explained requirement of normativity with reference to some examples in the British context: "It can hardly be contended that if once the House of Lords agrees with the House of Commons it is henceforth bound to agree with the lower House. Again, the fact that George V asked Mr Baldwin and not Lord Curzon to form a Government in 1922 does not of itself imply that the King must never in future appoint a peer as Prime Minister." ${ }^{, 64}$

Thus, the fact that the constitutional actors have once behaved in a certain way does not bind him to act in that way in the absence of normativity of the precedent. However, even normativity itself may be not enough to create a convention is well exemplified by its third element as provided below.

\subsection{Reason}

In the tests supplied by Jennings, we have just seen, normativity itself is not enough to establish the existence of a convention. In addition, there must be a reason for the rule. As Jennings puts it: "They do not exist for their own sake but because there are good reasons for them." ${ }^{65}$ Jennings goes on to elaborate:

For neither precedents nor dicta are conclusive. Something more must be added. As in the creation of law, the creation of a convention must be due to the reason of the thing because it accords with the prevailing political philosophy. It helps to make the democratic system operate; it enables the machinery of State to run more smoothly; and if it were not there friction would result. ${ }^{66}$

And Jennings finally concludes: "A single precedent with a good reason may by enough to establish the rule. A whole string of precedents without such a reason will be of no avail, unless it is perfectly certain that the persons concerned regarded them as bound by it." 67

The forceful analysis of Jennings clearly establishes that a precedent even with normative characteristic does not definitely prove anything. Rather, the normative

63 Jennings (n 2) 134-35 (emphasis added). Barnett sums up in this way: "A conventional rule may be said to exist when a traditional practice has been consciously adopted and recognized by those who operate the constitution as the correct manner in which to act in a given circumstance. A practice will be seen to have become a convention at the point at which failure to act in accordance with it gives rise to legitimate criticism." Barnett (n 50) 31.

64 Jennings (n 27) 6.

65 ibid 7 (emphasis added)

66 ibid 136 (emphasis added). I may quote another similar observation of Jennings in this regard: "Precedents create conventions because they have reasons of a general nature which relate them to the existing political conditions and because they are generally recognized to be sensible adaptations of existing conventional rules to meet changed or changing political conditions." Jennings (n 27) 8 (emphasis added).

67 Jennings (n 2) ibid. 
value of a precedent depends upon its being in accord with the prevailing political philosophy or with the principles of the constitution as currently accepted. Viscount Esher, an authority on precedents and confidential adviser of Edward VII and George $\mathrm{V}$, once observed that "Precedent, like analogy, is rarely conclusive". ${ }^{8}$ Approving Esher's view, Mackintosh has also argued that the precedents have "no independent existence or validity". ${ }^{69}$ Rather, they represent "a correct decision or action in certain political circumstances". ${ }^{70}$ Accordingly, "Searching for a precedent is really looking for a case where previous exponents of the constitution have solved a similar difficulty in an approved fashion." 71

From perusal of the views so far quoted, it can definitely be concluded that one way the previous difficulty may be said to have been solved in an approved fashion is when the convention accords with the prevailing political philosophy of the time. Indeed, the requirement of a convention's being in accord with the prevailing political philosophy has repeatedly been asserted by both judges and authors of constitutional law. It is to be found, for example, in the view of the Canadian Supreme Court in Reference re Amendment of the Constitution of Canada: "The main purpose of constitutional conventions is to ensure that the legal framework of the constitution will be operated in accordance with the prevailing constitutional values or principles of the period." "72 Barnett also observes to the similar effect: "Whether the outcome is deemed to be correct or not will depend on the acceptability of that action in light of current political practice." 73 Same is echoed in the words of Holdsworth: "these conventions are always directed to secure that the constitution works in practice in accordance with the prevailing constitutional theory of the time." ${ }^{, 74}$

In any system, one cannot understand completely what a thing is unless he understands what it actually does for the system. The element 'reason' of conventions should be considered with some more space and importance because this element in some measure reflects also on what conventions actually do for the constitutional system of a country. This method of stating the thing resembles more with the inquiry of purposes of conventions in any constitutional system. In relation to conventions, the inquiries as to the reasons for their existence, or alternatively the purposes they serve for the constitutional system are somewhat same. To clarify further, we have found a convention's being in accord with prevailing political philosophy as one of

68 Viscount Esher, The Influence of King Edward, and Essays on other Subjects (John Murray 1915) 167. ibid.

1 ibid (emphasis added).

72 (1981) 1 SCR 753. Quoted in Barnett (n 50) 39 (emphasis added). See also, Islam (n 2) 5-7. (Hereinafter Patriation Reference).

73 Barnett (n 50) 32 (emphasis added).

74 William (n 26). Quoted in Jennings (n 2) 83 (emphasis added). 
the reasons for their existence in a system. In terms of a purpose analysis, this may be stated in this way that conventions serve the purpose of working a constitution in accord with the prevailing political philosophy of the time. There is thus no distinction of substance between the inquiries as to reasons for their existence or purposes they serve for the constitutional system of a country. I now, therefore, turn to inquire into some purposes in addition to or different from a convention's being in accord with the prevailing political philosophy of time.

There is some literature that reflects on purposes conventions serve or ought to serve for the constitutional system of a country. This passage, for example, of Jennings is reflective of a convention's serving the purpose of bringing national cooperation and making the constitution work in accordance with its spirit: "A constitution does not work itself; it has to be worked by men. It is an instrument of national co-operation, and the spirit of co-operation is as necessary as the instrument. The constitutional conventions are the rules elaborated for effecting that cooperation." 75 A constitution should accommodate itself with the changing realities and needs of time. Conventions, in addition to formal amendment and judicial interpretation, may also serve this purpose. Jennings identifies this purpose of conventions as well: "Also, the effects of constitution must change with the changing circumstances of national life. New needs demand a new emphasis and a new orientation even when the law remains fixed. Men have to work the old law in order to satisfy the new needs. Constitutional conventions are the rules which they elaborate." ${ }^{, 76}$ Conventions may also serve the purpose of harmonizing relations and free development of law and legal institutions. Jennings in support of these purposes quotes from a conference report:

The association of constitutional conventions with law has long been familiar...It has provided a means of harmonizing relations where a purely legal solution of practical problems was impossible, would have impaired free development or would have failed to catch the spirit which gives life to institutions. Such conventions take their place among the constitutional principles and doctrines which are in practice regarded as binding and sacred whatever the powers of Parliaments may in theory be. ${ }^{77}$

The purposes of conventions thus far enumerated may generally hold good for constitutions operating in any jurisdiction. Dicey, in English jurisdiction, also sought to explore the purposes of conventions. In course of ascertaining the relation between laws and conventions, Dicey found a characteristic common to all or most of conventions of English Constitution. The 'common quality' Dicey identified in them is that they regulate the mode in which the discretionary powers of Crown and

\footnotetext{
Jennings (n 2) 82.

76 ibid.

77 Report of the Conference on the Operation of Dominion Legislation 1929 (Cmd.3479) 20. Quoted in Jennings, ibid, 85.
} 
Parliament ought to be exercised. ${ }^{78}$ But what end is secured by regulation of such discretionary powers? Dicey found it in securing the ultimate supremacy of the electorate as the true political sovereign of the state. In Dicey's own words:

They have all one ultimate object. Their end is to secure that Parliament, or the Cabinet which is indirectly appointed by Parliament, shall in the long run give effect to the will of that power which in modern England is the true political sovereign of the State - the majority of the electors or (to use popular though not quite accurate language ) the nation. ${ }^{79}$

This view Dicey repeatedly asserted: "Our modern code of constitutional morality secures, though in a roundabout way, what is called abroad the "sovereignty of the people"." "In short", Dicey reiterates again, "the validity of constitutional maxims is subordinate and subservient to the fundamental principle of popular sovereignty." view of ensuring ultimate supremacy of electorate as purposes of conventions in the context of English Constitution, his description may be applied for constitutions of other jurisdictions as well. Wheare, for example, justifies Dicey's thesis in the context of US Constitution. For a fuller understanding, I quote Wheare at some length:

When the power of veto of the head of the state is nullified, or when the electoral colleges of the United States cease to have any discretion to elect a President, we see the development of rules which are intended to remove obstacles from the giving effect to the will of the people.

The point is illustrated in a different way when we ask why, if convention has nullified the veto power of a King in a European country or in the British Commonwealth, the veto power of the President of the United States has not been nullified also. The answer would seem to be that the President is elected by the people and he may claim the right to express their will as much as Congress can.

Had the American President continued to be elected indirectly by the electoral colleges in practice as the law of the Constitution intended, it may well be that his veto power would have been greatly restricted, if not nullified, by convention. The explanation of the survival and indeed extended use of the President's veto power is, of course, more complicated than this, but the fact of his election by the people is certainly relevant to it. ${ }^{82}$

It has been said much, within the limited scope of the present study, on the elements of a convention (in light of Jennings test) particularly on the requirement of normativity and the reasons for they exist or purposes they serve for the constitutional system of a country. The three-fold tests of Jennings may be adopted

78 That is why Dicey described conventions as the "rules for determining the mode in which the discretionary powers of the crown (or of the Ministers as servants of the Crown) ought to be exercised." Dicey (n 1) 422-23. ibid 429. ibid 431. ibid 437. Wheare (n 2) 135-36 (paragraphs are creation of the author). 
by any person responsible for constitutional interpretation to determine within its jurisdiction the existence of a convention. The Supreme Court of Canada, for example, applied the Jennings test in Patriation Reference ${ }^{83}$ to determine within its jurisdiction the existence of a convention that the Constitution of Canada cannot be amended without first obtaining the consent of the Provinces.

\section{Conclusion}

To sum up the preceding analysis, mere precedent (act or omission of the constitutional authorities governing a particular situation) is not enough to establish the existence of a convention. The practices of political and constitutional dignitaries of the state should be normative involving in it the idea of 'rule' and 'obligation'. Furthermore, there must also be some reason for existence of the rule in the constitutional system of the state. Applying these three-fold identifying criteria of Jennings, the Supreme Court of Bangladesh found 'consultation' (with the Chief Justice in the matter of appointment of Judges of the Supreme Court) as an established constitutional convention in its system. ${ }^{84}$

To apply the Jennings test in the specific context of Idrisur Rahman, ${ }^{85}$ the Appellate Division of Bangladesh Supreme Court found an unbroken line of precedent (excepting the only departure made in 1994) ${ }^{86}$ of the executive's 'consultation' with the Chief Justice in the matter of appointment of Judges of the Supreme Court. The political actors in the precedents believed also that they were bound by the conventional rule of 'consultation' which satisfies the second requirement of a convention, normativity. The convention of 'consultation' in the instant case served the purpose of selecting the best from amongst those available for appointment as Judges of the Higher Judiciary. It is obvious that the Chief Justice of Bangladesh has the expertise knowledge about the ability and competency of a candidate for Judgeship in Superior Court. The Appellate Division thus found also the reasons for existence of the conventional rule of 'consultation' in its system.

This author is of the view that there is no problem if any Superior Court, as has been done by the Bangladesh Supreme Court ${ }^{87}$, seeks to determine the existence of a convention in its system applying the three-fold test of Jennings. The author, however, submits that the recognition criteria of a convention has nothing to do with the question of its enforcement since a Superior Court may recognize the existence of a convention in its system but may at the same time deny enforcing the same in the instant case. The Appellate Division of Bangladesh Supreme Court in its Idrisur Rahman ${ }^{88}$ decision

\footnotetext{
See, (n 72).

See, Manabjamin (n12), Idrisur Rahman (HCD) (n13) and Idrisur Rahman (AD) (n 14).

See, Idrisur Rahman (AD) (n 14).

See, above text accompanying notes 10 and 11 .

See, Manabjamin (n12), Idrisur Rahman (HCD) (n13) and Idrisur Rahman (AD) (n 14).

See, Idrisur Rahman (AD) (n 14).
} 
applying the Jennings test found 'consultation' as an established convention and just enforced the same against the executive government of the state. It is submitted that this particular one-dimensional approach or inquiry of the Court is not sufficient enough to determine the question of a convention's enforceability within the framework of any given constitution. If a political practice has not yet hardened into the norm of an established convention, no question of its recognition and/or enforcement arises. At the same time, if an established conventional rule is found to be in existence, its recognition and enforcement by courts cannot be said to be automatic. Rather, a court in such a case before enforcing the convention should enter into some interrelated themes and inquires of special importance in this regard. The related inquires may shortly be stated as below.

First, the courts should try to ascertain whether the conventional rule in the instant case is law itself or just a source of law. And any norm or rule existing in the system is law or not should be decided taking into account the relevant materials available in the legal system including, inter alia, the constitution and statutes. If it is found to be a law for the system, the court may or, rather may be said to be bound to enforce the convention in the given case. On the contrary, it may indeed be found that the conventional rule is just a source of law. In such a case, the convention may form part of the law of the land either by legislative incorporation in statutes or by judicial recognition in a concrete case. Second, a court's main function is not to make law but to interpret law in deciding disputes. Hence, a court's authority to make law by judicial precedents in appropriate cases though recognized and approved, the power is very much limited and always subject to some conditions and circumstances under the case. There is no reason why the same position should not obtain in cases of constitutional conventions also. It is, therefore, submitted that the questions relating to enforcement of constitutional conventions should be subjected to same limitations and judges exercising jurisdiction under any state constitution must of necessity see whether the conditions and circumstances are satisfied before they may enforce any convention in a given case. Third, courts should also deal whether this particular approach towards the question of enforcement of constitutional conventions commensurate in large measure with the nature and role of judicial power in a tripartite system of government or in the respective jurisdictions they are functioning.

Unfortunately, the Appellate Division of Bangladesh Supreme Court in its leading Idrisur Rahman ${ }^{89}$ decision on constitutional conventions did not at all address the above enumerated circumstances and conditions before enforcing the convention of 'consultation' against the executive government of the state. ${ }^{90}$ But, in view of the

89 ibid.

90 A discussion on the attending circumstances and conditions for determining the enforceability status of a convention in a given case demands for a separate full-fledged study on the subject. Any inquisitive researcher may undertake the task of filling up the vacuum of Supreme Court's Idrisur Rahman (see, ibid) verdict in this regard. The present author himself, however, hopes to undertake in future another research study on the subject. 
present author, the Court, in exercise of the judicial power of the state, was of necessity bound to deal with these essential aspects of judicial enforcement of conventional rules of the constitution. The Court thus simply failed to appreciate distinction between mere recognition and actual judicial enforcement of conventions in a given case. Furthermore, in Court's view, there is also just no distinction between 'laws of constitution' and an 'established constitutional convention'. ${ }^{91}$ The present author could not but respectfully disagree with this view of the Bangladesh Supreme Court. The English literature, particularly of Jennings, on which the Court heavily relied on for its reasoning and reaching conclusion $^{92}$, also maintains distinction between recognition and enforcement of conventions in a court of law. ${ }^{93}$

To conclude, the present study, in the wake of Appellate Division's enforcement of the convention of 'consultation' in Idrisur Rahman ${ }^{94}$, revisits the constituent elements of a convention. The study, therefore, as it claimed in the Introductory Part, deals only with one of the aspects involving the nature of conventional rules of constitution i.e. their recognition criteria. Conventions are just one of the various other 'non-legal' concepts of a constitution. In course of analysis of the constituent elements, the study reveals how convention as a 'non-legal' concept differs from those other 'non-legal' concepts of the constitution. The study both elaborates on the element 'reason' of conventions and relates this to purposes they serve for any constitutional system. This would help one knowing better the reasons for or legitimacy of existence of this body of rules in its constitutional system. To learn the effect of operation of conventions as well as the attending circumstances and conditions of their judicial enforcement are essential to the understanding of the nature and status of conventional rules within the framework of any given constitution. The present study enlightening one with the constituent elements and help removing the cloud and confusion that may persist over the very existence of the convention itself, would go a long way for any inquisitive reader interested in constitutional law to facilitate and enhance his understanding and knowledge of the interactive effect and enforceability status of conventions within the framework of any state constitutional jurisdiction.

\footnotetext{
See, notes 18 and 19 and the accompanying texts.

See, Idrisur Rahman (AD) (n 14).

See, Jennings (n 2) 107 and 121. The UK Supreme Court has reiterated the distinction between mere recognition and enforcement of conventions in a recent case also. See, $R$. (Miller) $v$ Secretary of State for Exiting the European Union [2017] U.K.S.C. 5. For detail of the case, see, Farrah Ahmed, Richard Albert, \& Adam Perry, 'Judging Constitutional Conventions' (2019) 17(3) International Journal of Constitutional Law 787. See also, Farrah Ahmed, Richard Albert, \& Adam Perry, 'Enforcing Constitutional Conventions' (2019) 17(4) International Journal of Constitutional Law 1146 (holding the view that courts should limit themselves to enforcing power-shifting conventions only). 